University of Wollongong

Research Online

Australian Institute for Innovative Materials -

Papers

Australian Institute for Innovative Materials

2012

\title{
A battery composed of a polypyrrole cathode and a magnesium alloy anode-Toward a bioelectric battery
}

Yong Kong

Changzhou University, China, ykong@uow.edu.au

Caiyun Wang

University of Wollongong, caiyun@uow.edu.au

Yang Yang

University of Wollongong, yy922@uow.edu.au

Chee O. Too

University of Wollongong, chee@uow.edu.au

Gordon G. Wallace

University of Wollongong, gwallace@uow.edu.au

Follow this and additional works at: https://ro.uow.edu.au/aiimpapers

Part of the Engineering Commons, and the Physical Sciences and Mathematics Commons

Research Online is the open access institutional repository for the University of Wollongong. For further information contact the UOW Library: research-pubs@uow.edu.au 


\title{
A battery composed of a polypyrrole cathode and a magnesium alloy anode- Toward a bioelectric battery
}

\author{
Abstract \\ A bioelectric battery can be implanted into the human body and relies on oxygen in the internal body fluid \\ to produce electrical energy. In this work, a battery that uses polypyrrole doped with a biological \\ polyelectrolyte (dextran sulfate, an anti-coagulant) as the cathode and bioresorbable Mg alloy (AZ61) as \\ the anode was developed. This battery exhibited a discharge capacity of $565 \mathrm{~mA} \mathrm{~h} \mathrm{~g}^{-1}$ in phosphate \\ buffered saline (PBS, $\mathrm{pH}=7.4$ ), a commonly used electrolyte in biological research; offering a specific \\ energy density of similar to $790 \mathrm{~W} \mathrm{~h} \mathrm{~kg}^{-1}$. The electrochemical properties of the cathode, anode and \\ battery itself were investigated in different aqueous electrolytes. Cyclic voltammetry, linear sweep \\ voltammetry, AC impedance, galvanostatic charge/discharge, and field-emission scanning microscopy \\ techniques were applied for characterization.

\section{Keywords} \\ polypyrrole, composed, cathode, magnesium, alloy, anode, toward, bioelectric, battery \\ Disciplines \\ Engineering | Physical Sciences and Mathematics

\section{Publication Details} \\ Kong, Y, Wang, C, Yang, Y, Too, CO, Wallace, GG (2012), A battery composed of a polypyrrole cathode and a \\ magnesium alloy anode-Toward a bioelectric battery, Synthetic Metals, 162(7/8), pp. 584-589.
}


Towards bioelectric battery - a battery composed of polypyrrole cathode and magnesium alloy anode

Yong Kong, ${ }^{1,2}$ Caiyun Wang, ${ }^{2}$ Yang Yang, ${ }^{2}$ Chee O. Too ${ }^{2}$ and Gordon G. Wallace ${ }^{2, *}$

1, Institute of Petrochemical Technology, Changzhou University, Changzhou 213164, P.R. China.

2, ARC Centre of Excellence for Electromaterials Science,

Intelligent Polymer Research Institute,

AIIM Facility, Innovation Campus,

University of Wollongong, NSW 2522, Australia.

* Prof. G. G. Wallace, corresponding author.

Tel.: +61 24221 3127; fax: +612 42983114 .

E-mail address: gwallace@uow.edu.au (G.G. Wallace). 


\section{Abstract}

A bioelectric battery can be implanted into the human body and relies on oxygen in the internal body fluid to produce electrical energy. In this work, a battery that uses polypyrrole doped with a biological polyelectrolyte (dextran sulfate, an anti-coagulant) as the cathode and bioresorbable $\mathrm{Mg}$ alloy (AZ61) as the anode was developed. This battery exhibited a discharge capacity of $565 \mathrm{~mA} \mathrm{~h} \mathrm{~g}^{-1}$ in phosphate buffered saline (PBS, $\mathrm{pH}=7.4$ ), a commonly used electrolyte in biological research; offering a specific energy density of $\sim 790 \mathrm{~W} \mathrm{~h} \mathrm{~kg}{ }^{-1}$. The electrochemical properties of the cathode, anode and battery itself were investigated in different aqueous electrolytes. Cyclic voltammetry, linear sweep voltammetry, AC impedance, galvanostatic charge/discharge, and field-emission scanning microscopy techniques were applied for characterization.

Key words: Bioelectric battery, conducting polymers, polypyrrole, magnesium alloy. 


\section{Introduction}

The general power source requirements for implantable biomedical devices include safety, reliability, high energy density and predictability of performance [1]. Since the implantation of lithium-iodine batteries in the cardiac pacemaker [2], lithium batteries have become the predominant power source for implantable devices [3]. However, the life-time of these batteries is limited and they need to be changed periodically by inconvenient surgery. Bioelectrochemical power sources can harness the supply of electric power from energy sources of the body. These include the bioelectric battery (i.e. biogalvanic cell) and the biofuel cell [4]. Biofuel cells use biocatalysts, either bio-molecules such as enzymes or even whole living organisms (microbes) to catalyze oxidation of biomass-based materials for generating electrical energy [5,6]. The most efficient glucose/oxygen biofuel cell reported so far could produce a power density of $1.45 \pm 0.24 \mathrm{~mW} \mathrm{~cm}^{-2}$ at $0.3 \mathrm{~V}$ [7]. For a microbial based fuel cell, a maximum power density of $73.3 \mathrm{~mW} \mathrm{~m}^{-2}$ with an average voltage output of $0.308 \mathrm{~V}$ was reported [8], which is insufficient to power most implantable bionic devices [9]. Furthermore, the immobilization of the enzyme on appropriate electrode substrates to ensure high activity and stability remains a challenge [10].

Recently increased attention has been paid to the development of bioelectric batteries $[11,12]$. Bioelectric batteries can be implantable in the body and rely on oxygen in the internal body fluid to produce a voltage between the anode and the cathode. Normally the anode material used is an active metal such as $\mathrm{Mg}$ metal or $\mathrm{Mg}$ alloy. The cathode is Pt or Ti with a layer of catalyst coating which can increase the surface area resulting in a fast reaction and increased voltage generation. Common catalysts for oxygen reduction include Pt, bifunctional electrocatalysts and metal 
oxides [13]. Poly( 3,4- ethylenedioxythiophene)( PEDOT), an inherently conducting polymer (ICP), can act as an $\mathrm{O}_{2}$ reduction catalyst and its $\mathrm{O}_{2}$ conversion rates were comparable with those of Pt-catalyzed electrodes of the same geometry [14]. A battery, composed of a polymer PEDOT cathode and a Mg anode, also exhibited the discharge properties of a $\mathrm{Mg} /$ air battery in a near-saturated aqueous solution of $\mathrm{LiCl}$ and $\mathrm{MgCl}_{2}[15]$.

Polypyrrole, another important member of the ICP family has several attractive features, such as affording the ability to readily tune chemical, electronic and mechanical properties [16]. It has been reported that undoped polypyrrole can be re-oxidized by oxygen $[17,18]$. A high discharge capacity can therefore be expected for a battery with polypyrrole cathode when $\mathrm{O}_{2}$ is available in the electrolyte. For implantable power sources, the use of an aqueous electrolyte containing biocompatible salts is preferred over organic solvent based electrolytes. Polypyrrole like other members of ICPs has been shown to be biocompatible, with potential applications in biomedical implants. Previous studies have shown the useful role polypyrrole can play in tissue engineering, when implanted within the human body $[19,20]$. Polypyrrole, therefore appears to be an excellent candidate for use as an active component within a bioelectric battery.

In this work polypyrrole containing a biological polyelectrolyte, dextran sulfate (an anti-coagulant), as dopant was used. The use of a biomolecule as dopant is known to increase biocompatibility [21].The polypyrrole cathode and a bioadsorbable $\mathrm{Mg}$ alloy anode were combined within an aqueous electrolyte. This battery exhibited a discharge capacity of $565 \mathrm{~mA} \mathrm{~h} \mathrm{~g}^{-1}$ in phosphate buffered saline (PBS, $\mathrm{pH}=7.4$ ), a buffer solution commonly used in biological research; offering a specific energy density of about $790 \mathrm{~W} \mathrm{~h} \mathrm{~kg}^{-1}$. 


\section{Experimental}

2.1 Materials.

Magnesium chloride, sodium chloride, magnesium nitrate and sodium nitrite were all purchased from Ajax Finechem Pty Ltd. Dextran sulfate sodium salt (AV. MW 500,000), pyrrole and phosphate buffered saline were obtained from SigmaAldrich. Magnesium alloy (AZ61) was kindly provided by Dr. Yijing Wang from the New Energy Materials Research Institute in Nankai University. AZ61 was polished with fine sandpaper and degreased with acetone prior to use. Pyrrole was distilled and stored at $-12{ }^{\circ} \mathrm{C}$. All other chemicals were used as supplied. All the solutions were prepared with Milli-Q water of $18 \mathrm{M} \Omega$.

\subsection{PPy Electrodeposition}

Following the method described by Gilmore et al [22], polypyrrole film was electrosynthesized galvanostatically on a stainless steel mesh substrate (Hongye Stainless Steel Wire Cloth Co. Ltd.) at a current density of $0.5 \mathrm{~mA} \mathrm{~cm}{ }^{-2}$ from an aqueous solution containing $0.2 \mathrm{M}$ pyrrole and $2 \mathrm{mg} \mathrm{ml}^{-1}$ dextran sulfate (DS). This reaction was performed in a three-electrode system with a stainless steel mesh counter electrode and a $\mathrm{Ag} / \mathrm{AgCl}(3 \mathrm{M} \mathrm{NaCl})$ reference electrode. The solution was deoxygenated with nitrogen prior to the electropolymerization, and the amount of charge consumed during this process was $1.0 \mathrm{C} \mathrm{cm}^{-2}$. The product obtained was rinsed with $\mathrm{H}_{2} \mathrm{O}$ and vacuum dried at $50^{\circ} \mathrm{C}$ for 18 hours prior to further studies.

\subsection{Characterization}


Scanning Electron Microscopy. The surface morphologies of the electrodes were investigated by means of a cold-field-gun field emission microscope (FESEM, JEOL JSM-7500F) with a secondary electron detector. Samples were mounted on a stage using adhesive carbon tape.

Cyclic voltammetry (CV), linear sweep voltammetry (LSV) and electrochemical impedance (EIS). All the experiments were carried out in a standard three-electrode system comprising a Pt mesh counter electrode, a $\mathrm{Ag} / \mathrm{AgCl}(3 \mathrm{M} \mathrm{NaCl})$ reference electrode, and a PPy film on stainless steel mesh as working electrode. Cyclic voltammetry of the polymer was performed using a Solartron SI 1287. The electrodes were immersed in the different electrolytes (1.0 $\mathrm{M} \mathrm{MgCl}_{2}$, saturated $\mathrm{MgCl}_{2}$, $1 \mathrm{M} \mathrm{NaCl}$, PBS and mixed electrolyte of $2.6 \mathrm{M} \mathrm{Mg}\left(\mathrm{NO}_{3}\right)_{2}+3.6 \mathrm{M} \mathrm{NaNO} \mathrm{Na}_{2}$, and scanned between -0.5 to $+0.5 \mathrm{~V}$ ( $\mathrm{vs} \mathrm{Ag} / \mathrm{AgCl}$ ) at a scan rate of $25 \mathrm{mV} \mathrm{s}^{-1}$. Electrochemical impedance spectra were measured potentiostatically using a PCI4/750 Potentiostat/Galvanostat/ZRA (Gamry Instruments, Inc. USA). The frequency range was from $100 \mathrm{kHz}$ to $0.1 \mathrm{~Hz}$ with an $\mathrm{AC}$ perturbation of $5 \mathrm{mV}$. Linear sweep voltammetry (LSV) of $\mathrm{Mg}$ anode was also investigated in these five electrolytes using an EG\&G PAR 363 Potentiostat/Galvanostat and EChem v 1.3.2 software (AD Instruments) at a scan rate of $10 \mathrm{mV} \mathrm{s}^{-1}$; starting from open circuit potentials to $-0.2 \mathrm{~V}$ (vs $\mathrm{Ag} / \mathrm{AgCl})$.

\subsection{Battery testing}

The cells were fabricated with PPy cathodes $\left(1 \times 1 \mathrm{~cm}^{2}\right)$ and $\mathrm{Mg}$ alloy anodes $\left(2 \times 5 \mathrm{~cm}^{2}\right)$ in a one component cell with $20 \mathrm{ml}$ of electrolyte, and tested using a battery-testing device (Neware Electronic Co.). The cells were discharged galvanostatically at a current density of $30 \mathrm{~mA} \mathrm{~g}^{-1}$ (based on the amount of PPy) to a cut-off cell voltage of $1.0 \mathrm{~V}$. 


\section{Results and discussions}

\subsection{Surface morphology of PPy-DS}

Initial studies involved the electrodeposition of PPy-DS onto a stainless steel mesh substrate. Using the galvanostatic conditions described in the Experimental Section a smooth black polypyrrole film (doped with dextran sulphate (DS)), was observed to grow on the substrate. This material exhibited a micro-porous structure with interconnected flowers at high magnification (Figure 1). This porous structure should maximize the electroactive surface area and facilitate ion transport.

\subsection{Cyclic voltammograms}

Cyclic voltammetry was used to characterise the intrinsic redox reactions. PPy-DS undergoes in different aqueous electrolytes (Figure 2). For ICPs, the reduction process is associated with concomitant expulsion of anions or the insertion of cations as shown in Equations (1) and (2), respectively, and vice versa for the oxidation reaction. Anions $\left(\mathrm{A}^{-}\right.$- Equation 1) are expelled into the solution during the reduction process [23]. However, when immobile counter-anions are employed in the conjugated conducting polymers, the redox mechanism involves the entry of cations $\left(\mathrm{X}^{+}\right.$- Equation 2) during reduction and expulsion during oxidation [24]. DS, being a large size polyelectrolyte/polyanionic dopant with average molecular weight of 500,000 (as shown in Scheme 1) was expected to promote cationic movement when PPy-DS was electrochemically reduced (Equation 2), i.e. the less mobile $\mathrm{DS}^{-}$would attract cations to achieve charge neutrality in the polymer backbone. A higher ionic activity coefficient of the cation will induce higher electric response during the cyclic sweep scan for PPy-DS. 

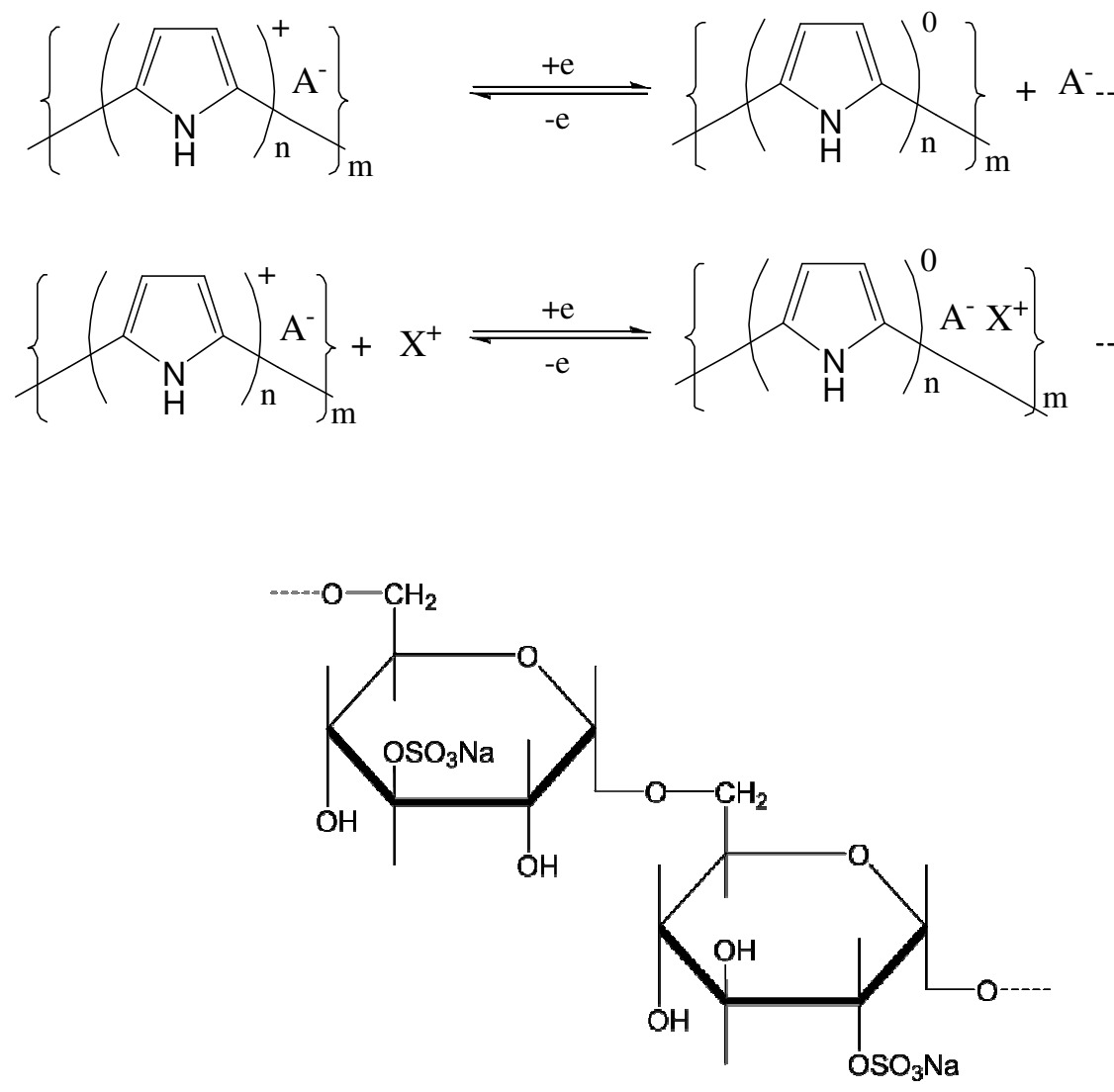

Scheme 1. Schematic structure of dextran sulphate (DS)

It is noted that this polymer electrode exhibited similar electroactivity in saturated $\mathrm{MgCl}_{2}, 1 \mathrm{M} \mathrm{NaCl}$ and $\mathrm{PBS}$, all with broad redox peaks and roughly the same integrated area under the respective voltammetric waves indicating the available charge/discharge capacity during the scan (Figure $2 \mathrm{a}, 2 \mathrm{~b}$ and $2 \mathrm{c}$ ). The highest current and integrated area was obtained in $1 \mathrm{M} \mathrm{MgCl}_{2}$, which can be ascribed to the highest ionic activity coefficient of $\mathrm{Mg}^{2+}$ in this electrolyte [25]. The CV of PPy-DS in the mixed electrolyte of $\mathrm{Mg}\left(\mathrm{NO}_{3}\right)_{2}(2.6 \mathrm{M})$ and $\mathrm{NaNO}_{2}$ (3.6M), for reasons not apparent, exhibited better defined anodic and cathodic peaks (Fig. 2e). All these results show that the electroactivity of this polymer was affected by the electrolyte, particularly the ionic activity of cations. The optimal performance was obtained in $1 \mathrm{M} \mathrm{MgCl}_{2}$.

\subsection{AZ61 electrode corrosion}


The choice of Mg alloy (AZ61) as anode is based on the fact that it provides a high energy density, is low in cost, and is bioresorbable [26, 27]. Moreover, $\mathrm{Mg}$ alloys are commonly used for $\mathrm{Mg}$-air or $\mathrm{Mg}$ reserve batteries instead of pure $\mathrm{Mg}$ metals due to their improved corrosion resistance and better discharge characteristics [28].

It is well known that the corrosion rate depends on the electrolyte used. Figure 3 displays the linear sweep voltammograms of AZ61 in different electrolytes. The anodic dissolution current densities of AZ61 increased as the potential was swept from the open circuit potential (OCP) to $-0.2 \mathrm{~V}$ in all five electrolytes. However, it maintained a steady state in the potential range of -1.24 to $-1.11 \mathrm{~V}$ indicative of passivation phenomena in the mixed electrolyte of $\mathrm{Mg}\left(\mathrm{NO}_{3}\right)_{2}(2.6 \mathrm{M})$ and $\mathrm{NaNO}_{2}(3.6$ M). The higher anodic current corresponding to the corrosion rate in the potential range of OCP to $-1.0 \mathrm{~V}$ in these electrolytes was in the order of $\mathrm{a}>\mathrm{b}>\mathrm{c}>\mathrm{d}>\mathrm{e}$. High anodic current density also means high electroactivity of AZ61 electrode and short life of the batteries with it as anode material. It is also noted that higher anodic current has been shown in chloride media, $\mathrm{MgCl}_{2}$ (a), saturated $\mathrm{MgCl}_{2}$ (b) and $\mathrm{NaCl}$ (c), with the sequence of $a>b>c$.

\subsection{Battery discharge performance}

The discharge characteristics of the cell composed of PPy-DS cathode and AZ61 anode was investigated in all these five electrolytes, and shown in Figure 4. The discharge capacities obtained were $68,90,396,565$ and $873 \mathrm{~mA} \mathrm{~h} \mathrm{~g}^{-1}$ in the electrolyte of a, b, c, d and e, respectively. The discharge capacity from the lowest to the highest was in the sequence of $\mathrm{a}<\mathrm{b}<\mathrm{c}<\mathrm{d}<\mathrm{e}$, which was opposite to their anodic current density order $(a>b>c>d>e)$. The discharge capacity of this cell in PBS and mixed electrolyte of magnesium nitrate and sodium nitrite was much higher 
than the theoretical capacity of polypyrrole even without taking the dopant into account (136 mA h g $\mathrm{g}^{-1}$. Two reasons might be given to explain such high discharge capacity; one is that PPy-DS can be used as a catalyst as in the case of PEDOT for oxygen reduction process, apart from its redox properties [14]. Another one is that the reduced or undoped polypyrrole produced during the discharge process can be reoxidized by oxygen contained in the electrolyte and retained its electroactivity $[17,18]$. This cell was almost restored to its initial discharge properties when replacement of freshly polished Mg alloy anode and fresh electrolyte were utilized, characteristics of a typical metal air battery (mechanically rechargeable, no figures shown) [29]. The discharge capacity of this bioelectric battery was mainly limited by the uncontrolled corrosion of AZ61. Therefore, this battery is primarily a $\mathrm{Mg} / \mathrm{O}_{2}$ battery. However, when the PPy-DS electrode was replaced by blank stainless steel mesh, the cell exhibited a much poorer performance when coupled with the same AZ61 anode. PPyDS did participate in the reaction. The function of PPy-DS in this type of battery was related to $\mathrm{O}_{2}$ as summarized in addition to its redox properties.

This battery exhibited a discharge capacity of $565 \mathrm{~mA} \mathrm{~h} \mathrm{~g}{ }^{-1}$ in phosphate buffered saline (PBS), a biologically compatible electrolyte; offering a specific energy density of about $790 \mathrm{~W} \mathrm{~h} \mathrm{~kg}^{-1}$. This power is higher than that of a Li// $\mathrm{I}_{2}$ battery (220$280 \mathrm{~W} \mathrm{~h} \mathrm{~kg}^{-1}$ ), commonly used battery in pacemaker [9]. This power is sufficient to drive implantable medical devices that require low power densities (less than $100 \mu \mathrm{W}$ ) such as a pacemaker or biomonitoring systems. In addition, this type of battery system can also be used as a drug release device if an appropriate drug was doped in the polymer matrix (Equation 1) when producing the electric energy, as reported by Wallace et al [30].

3.5 Investigation of AZ61 anode before or after discharge 
After the discharge experiment the AZ61 electrode was treated in an ultrasonication bath $\left(\mathrm{H}_{2} \mathrm{O}\right)$ for 5 mins, followed by rinsing with $\mathrm{H}_{2} \mathrm{O}$. Cracks were observed on the surface of the AZ61 electrode due to the observed hydrogen evolution (Figure 5). The images obtained for the AZ61 electrode after discharge in $\mathrm{MgCl}_{2}$ are not shown here due to its similarity with that observed in $\mathrm{NaCl}$. A greater number of cracks were formed on the AZ61 electrode after use in PBS or the mixed electrolyte of $\mathrm{Mg}\left(\mathrm{NO}_{3}\right)_{2}$ and $\mathrm{NaNO}_{2}$. This is attributed to the more severe corrosion obtained with longer exposure to the electrolyte due to the higher discharge capacity obtained. It was also observed that the AZ61 electrode surface was covered with a layer of compound, most likely $\mathrm{Mg}(\mathrm{OH})_{2}$, formed according to the following reaction (Equation 3) [28]. This layer resisted ultrasonic rinsing with $\mathrm{H}_{2} \mathrm{O}$, indicating strong adherence to AZ61, which might have inhibited AZ61 from the deeper discharge leading to formation of denser cracks.

$$
2 \mathrm{Mg}+\mathrm{O}_{2}+2 \mathrm{H}_{2} \mathrm{O} \longrightarrow 2 \mathrm{Mg}(\mathrm{OH})_{2}
$$

EIS is a widely used experimental method to gain a deeper insight into electrochemical systems. The corresponding Nyquist plots of the AZ61 electrode after discharge experiments are shown in Figure 6. A high impedance was observed after use in PBS or the mixed electrolyte of $\mathrm{Mg}\left(\mathrm{NO}_{3}\right)_{2}(2.6 \mathrm{M})$ and $\mathrm{NaNO}_{2}(3.6 \mathrm{M})$, and this can be ascribed to the dense cracks formed during the discharge experiment. In chloride media AZ61 exhibited low impedances and a small inductive loop characteristic of corrosion processes; which might be ascribed to the high anodic currents of AZ61 in this type of electrolyte and the fast sedimentation of corrosion product onto its surface thus inhibiting AZ61 from the deeper discharge leading to formation of denser cracks. 


\section{Conclusions}

The battery system consisting of a biocompatible polypyrrole cathode (PPyDS) and a Mg alloy anode, is primarily a Mg/air battery. This battery exhibited an energy density of $\sim 790 \mathrm{~W} \mathrm{~h} \mathrm{~kg}^{-1}$ with commonly used biological media - PBS as electrolyte, which should be sufficient to drive some implantable devices requiring low power densities such as a pacemaker or biomonitoring systems. The electroactivity of PPy-DS could be ascribed to the ionic activity of aqueous electrolyte cations. Its contribution to such battery performance was related with its redox properties and its interaction with $\mathrm{O}_{2}$ contained in the electrolyte. This battery performance was mainly limited by the oxidation of the AZ61 electrode. A high anodic dissolution current of AZ61 corresponded to a high corrosion rate leading to low discharge capacity and a shorter battery life. In addition, this battery also has the potential to be used as a drug release device when simultaneously producing the electrical energy. The investigation of this battery system in the simulated body fluid (SBF) containing protein is undergoing.

\section{Acknowledgement}

Financial support from the Australian Research Council is gratefully acknowledged. 


\section{References}

[1] E. S. Takeuchi, R. A. Randolph A. MRS Bulletin (2002) 624-626.

[2] G. Antonioli, F. Baggioni, F. Consiglio, G. Grassi, R. LeBrun, F. Zanardi,

Minerva Med. 64 (1973) 2298-2304.

[3] C.F. Holms, J. Power Sources 97-8 (2001) 739-741.

[4] J.R. Rao and G. Richter, Naturwissenschaften 61 (1974) 200-206.

[5] B.E. Logan, B. Hamelers, R. A. Rozendal, U. Schrorder, J. Keller, S. Freguia, P. Aelterman, W. Verstraete, K. Rabaey, Environ. Sci. Technol. 40 (2006) 5181-5192.

[6] R. A. Bullen, T.C. Arnot, J. B. Lakeman, F. C. Walsh, Biosens. Bioelectron. 21 (2006) 2015-2045.

[7] H. Sakai, T. Nakagawa, Y. Tokita, T. Hatazawa, T. Ikeda, S. Tsujimura, K. Kano, Energy Environ. Sci. 2 (2009) 133-138.

[8] Y. han, C. Yu, H. Liu, Biosensors \& Bioelectronics 25 (2010) 2156-2160.

[9] M. Rasouli, L.S.T. Phee, Expert Rev. Med. Devices 7 (2010) 693-709.

[10] S. C. Barton, J. Gallaway, P. Atanassov, Chem. Rev. 104 (2004) 4867-4886.

[11] R. Rodriguez, M. Lora, US 2010/0055570 A1, 2010.

[12] N. Jiang, G.A. Bornzin, J. W. Poore, US 2010/0114236 A1, 2010.

[13] J. S. Lee, S. T. Kim, R. Cao, N. S. Choi, M. Liu, K. T. Lee, J. Cho, Adv. Energy Mater. 1 (2011) 34-50.

[14] B. Winther-Jensen, O. Winther-Jensen, M. Forsyth, D.R. MacFarlane, Science 321 (2008) 671-674.

[15] B. Winther-Jensen, M. Gaadingwe, D. R. Macfarlane, M. Forsyth, Electrochimica Acta 20 (2008) 5881-5884.

[16] Wallace, G.G., Spinks, G.M., Kane-Maguire, L.A.P., Teasdale, P.R. "Conductive Electroactive Polymers: Intelligent Polymer Systems" Third Edition CRC Press, Taylor \& Francis Group, Boca Raton, 2008.

[17] A. Wu, E.C. Venancio, A.G. MacDiarmid, Synth. Met. 157 (2007) 303-310.

[18] J. Lei, C.R. Martin, Chem. Mater. 7 (1995) 578-584.

[19] N.K. Guimard, N. Gomez and C. Schmidt, Prog. Polym. Sci. 32 (2007) 876-921.

[20] P.M. George, A.W. Lyckman, D.A. LaVan, A. Hegde, Y. Leung, R. Avasare, C. Testa, P.M. Alexander, R. Langer and M. Sur, Biomaterials 26 (2005) 3511-3519.

[21] X. Cui, V.A. Lee, Y. Raphael, J.A. Wiler, J.F. Hetke, D.J. Anderson, D.C.

Martin, J. Biomed. Mater. Res. 56 (2001) 261-272.

[22] K.J. Gilmore, M. Kita, Y. Han, M.J. Higgins, S.E. Moulton, G.M. Clark, R.

Kapsa, G.G. Wallace, Biomaterials 30 (2009) 5292-5304.

[23]A. Talaie and G.G. Wallace, Synth. Met. 63 (1994) 83-88.

[24] K. Naoi, M. Lien, W.H. Smyrl, J. Electrochem. Soc. 138 (1991) 440-445.

[25] J. Kielland, J. Am. Chem. Soc. 59 (1937) 1675-1678.

[26] B. Peng, J. Liang, Z. Tao, J. Chen, J. Mater. Chem. 19 (2009) 2877-2883.

[27] H.S. Brar, M. O. Platt, M. Sarntinoranont, P.I. Martin, M.V. Manuel, JOM 61 (2009) 31-34.

[28] S. Sathyanarayana, N. Munichandraiah, J. Appl. Electrochem. 11 (1981) 33-39.

[29] D. Linden, T.B. Reddy, Handbook of Batteries, 3rd ed., McGraw-Hill, New

York 2002.

[30] S.E. Moulton, M.D. Imisides, R.L. Shepherd, G.G. Walalce, J. Mater. Chem. 30

(2008) 3608-3613. 


\section{Captions:}

Figure 1 FESEM images of PPy-DS electrodeposited on stainless steel mesh at different magnifications.

Figure 2 Cyclic voltammograms of PPy-DS in different electrolytes at a scan rate of $25 \mathrm{mV} \mathrm{s}^{-1}$. (a) $1.0 \mathrm{M} \mathrm{MgCl}_{2}$; (b) saturated $\mathrm{MgCl}_{2}$; (c) $1 \mathrm{M} \mathrm{NaCl}$; (d) PBS; (e) mixed electrolyte of $2.6 \mathrm{M} \mathrm{Mg}\left(\mathrm{NO}_{3}\right)_{2}$ and $2.6 \mathrm{M} \mathrm{NaNO}$.

Figure 3 Linear sweep voltammograms of AZ61 in different electrolytes: $1 \mathrm{M} \mathrm{MgCl}_{2}$ (a), saturated $\mathrm{MgCl}_{2}$ (b), $1 \mathrm{M} \mathrm{NaCl}$ (c), PBS (d) and mixed electrolyte of $\mathrm{Mg}\left(\mathrm{NO}_{3}\right)_{2}$ $(2.6 \mathrm{M})$ and $\mathrm{NaNO}_{2}(3.6 \mathrm{M})(\mathrm{e})$. Scan rate: $10 \mathrm{mV} \mathrm{s}^{-1}$. Potential range: open circuit potential to $-0.2 \mathrm{~V}$ versus $\mathrm{Ag} / \mathrm{AgCl}(3 \mathrm{M} \mathrm{NaCl})$.

Figure 4 The discharge curves of the cell composed of a PPy-DS cathode and AZ61 anode in different electrolytes at the discharge current density of $30 \mu \mathrm{Ag}^{-1}$. (a) $1 \mathrm{M}$ $\mathrm{MgCl}_{2}$; (b) saturated $\mathrm{MgCl}_{2}$; (c) $1 \mathrm{M} \mathrm{NaCl}$; (d) PBS and (e) mixed electrolyte of $\mathrm{Mg}\left(\mathrm{NO}_{3}\right)_{2}(2.6 \mathrm{M})$ and $\mathrm{NaNO}_{2}(3.6 \mathrm{M})$.

Figure 5 FESEM images of freshly polished AZ61 (A) and after discharge in different electrolytes of PBS (B), mixed electrolyte of $\mathrm{Mg}\left(\mathrm{NO}_{3}\right)_{2}$ (2.6 M)and $\mathrm{NaNO}_{2}$ $(3.6 \mathrm{M})(\mathrm{C})$, and $1.0 \mathrm{M} \mathrm{NaCl}(\mathrm{D})$.

Figure 6 Nyquist plots for AZ61 anode after discharge experiments in different electrolytes: $1 \mathrm{M} \mathrm{MgCl}_{2}$ (a), saturated $\mathrm{MgCl}_{2}$ (b), $1 \mathrm{M} \mathrm{NaCl}$ (c), PBS (d) and mixed electrolyte of $\mathrm{Mg}\left(\mathrm{NO}_{3}\right)_{2}(2.6 \mathrm{M})$ and $\mathrm{NaNO}_{2}(3.6 \mathrm{M})$ (e). 


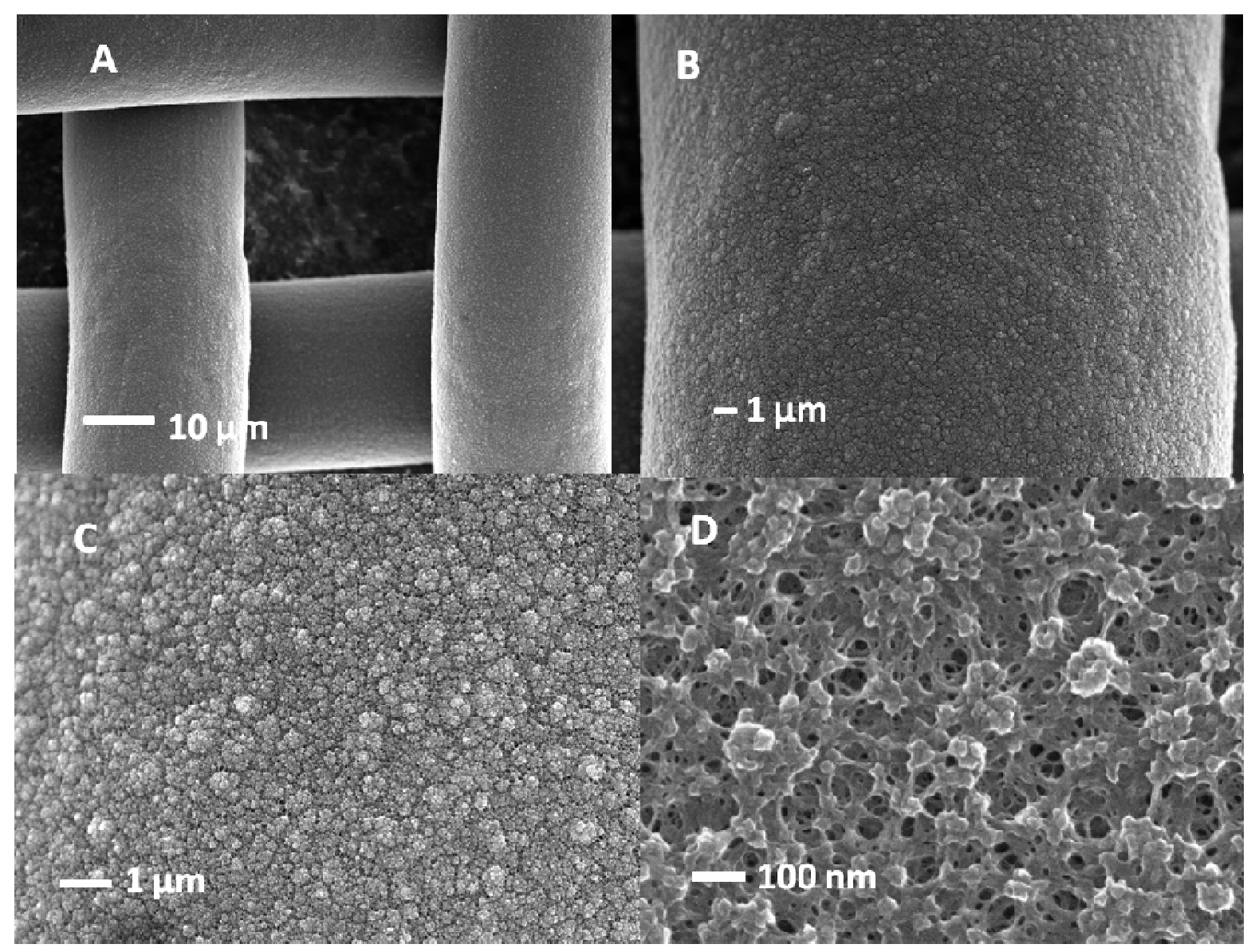

Figure 1 


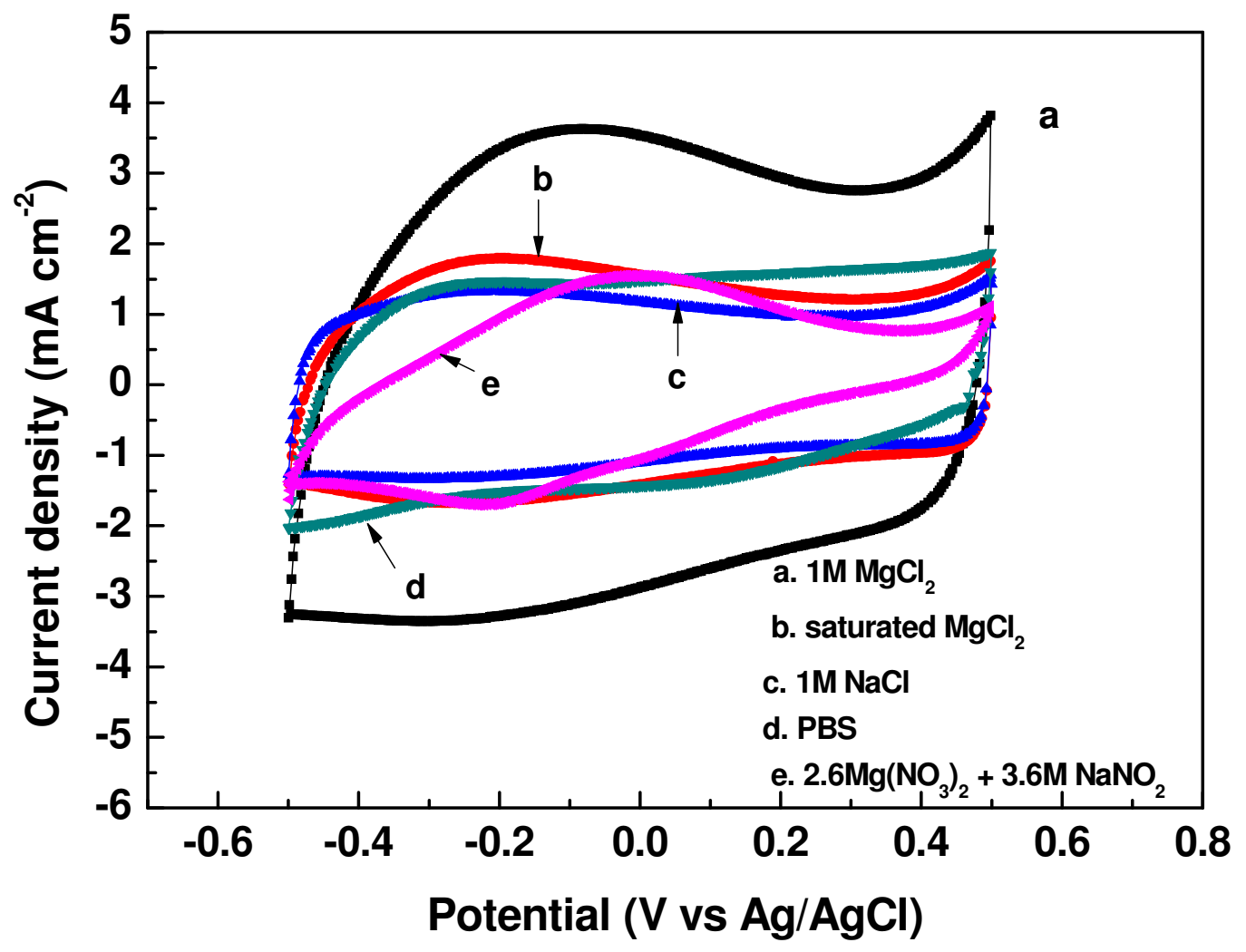

Figure 2 


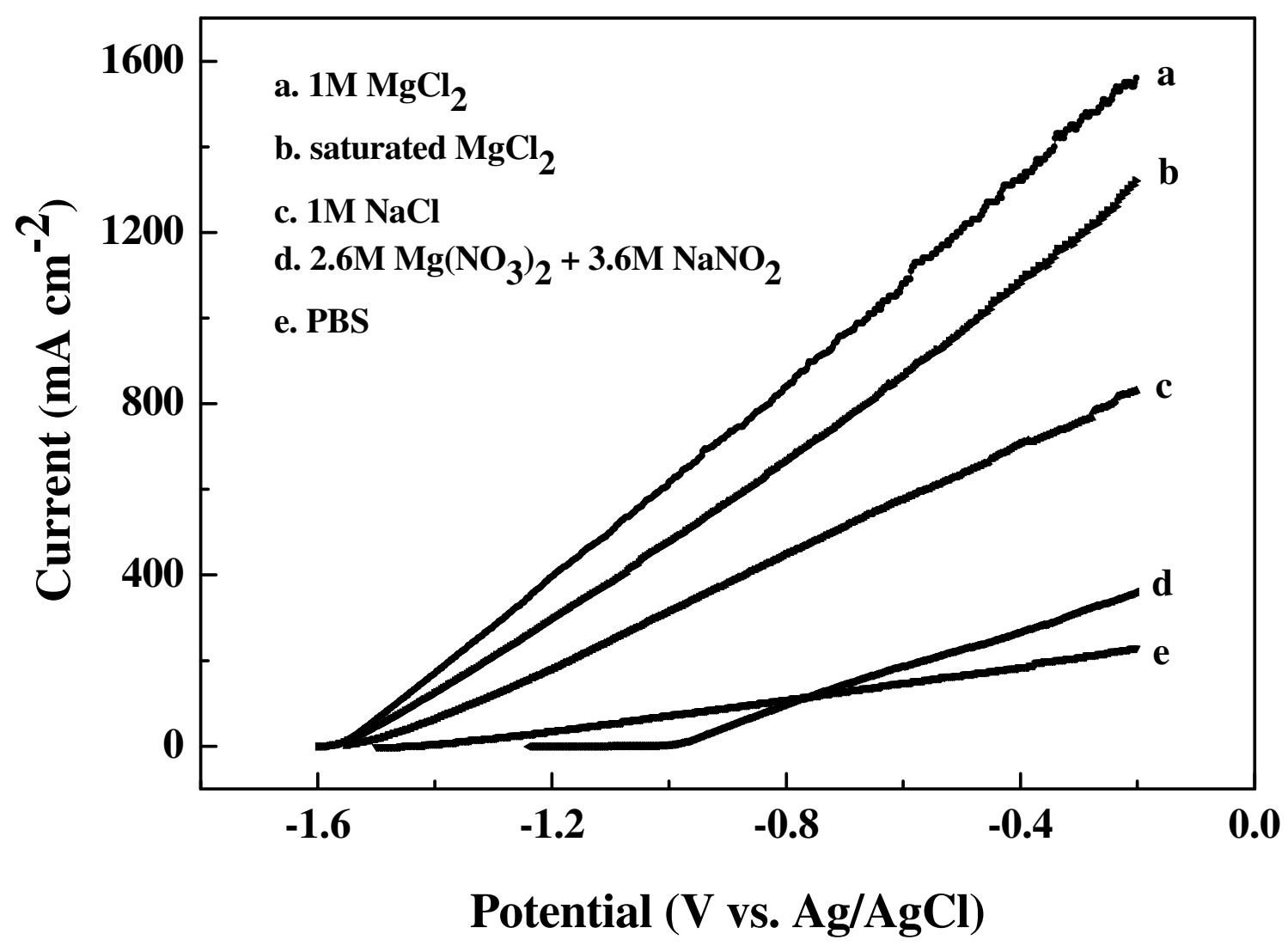

Figure 3 


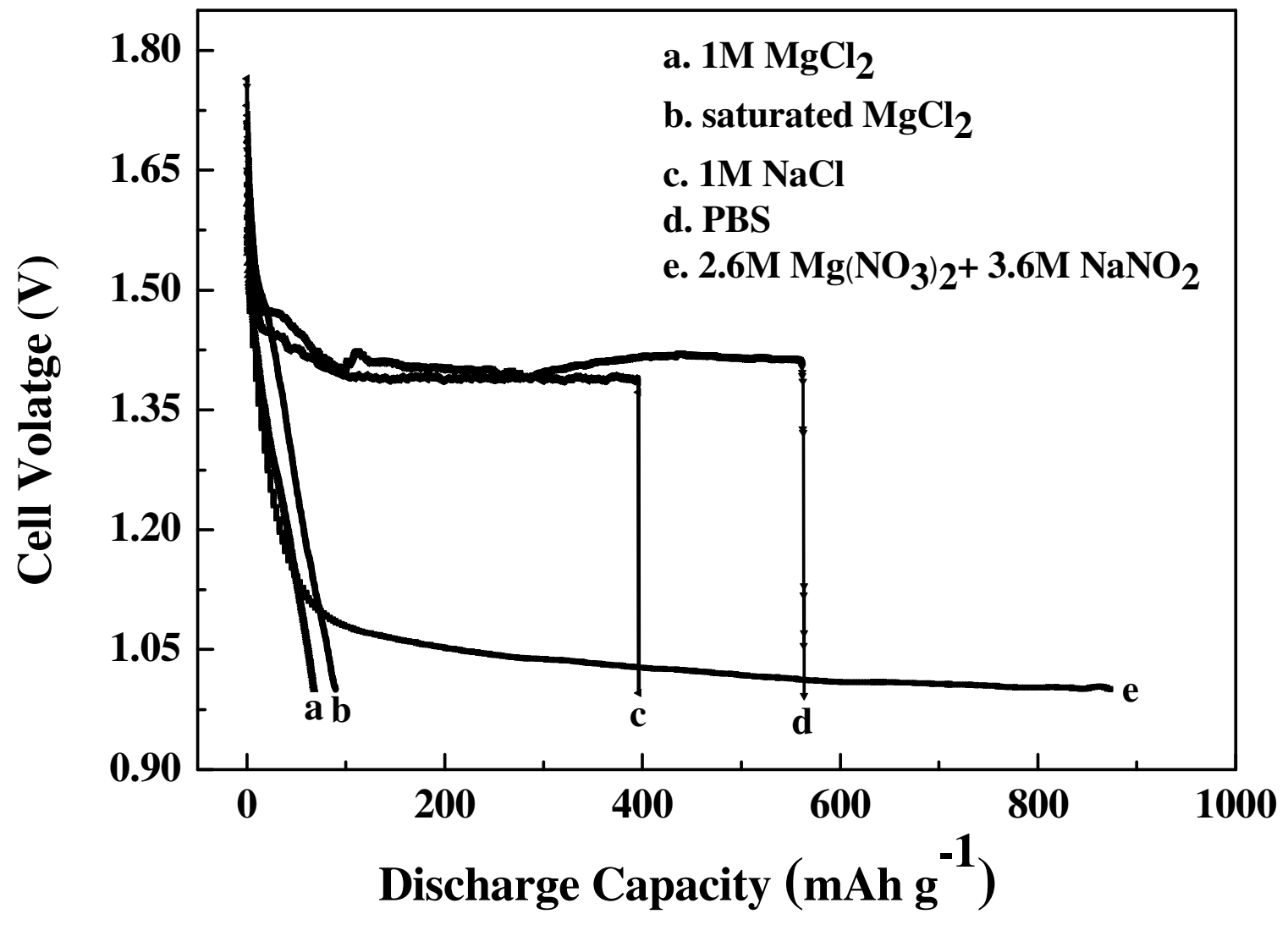

Figure 4 


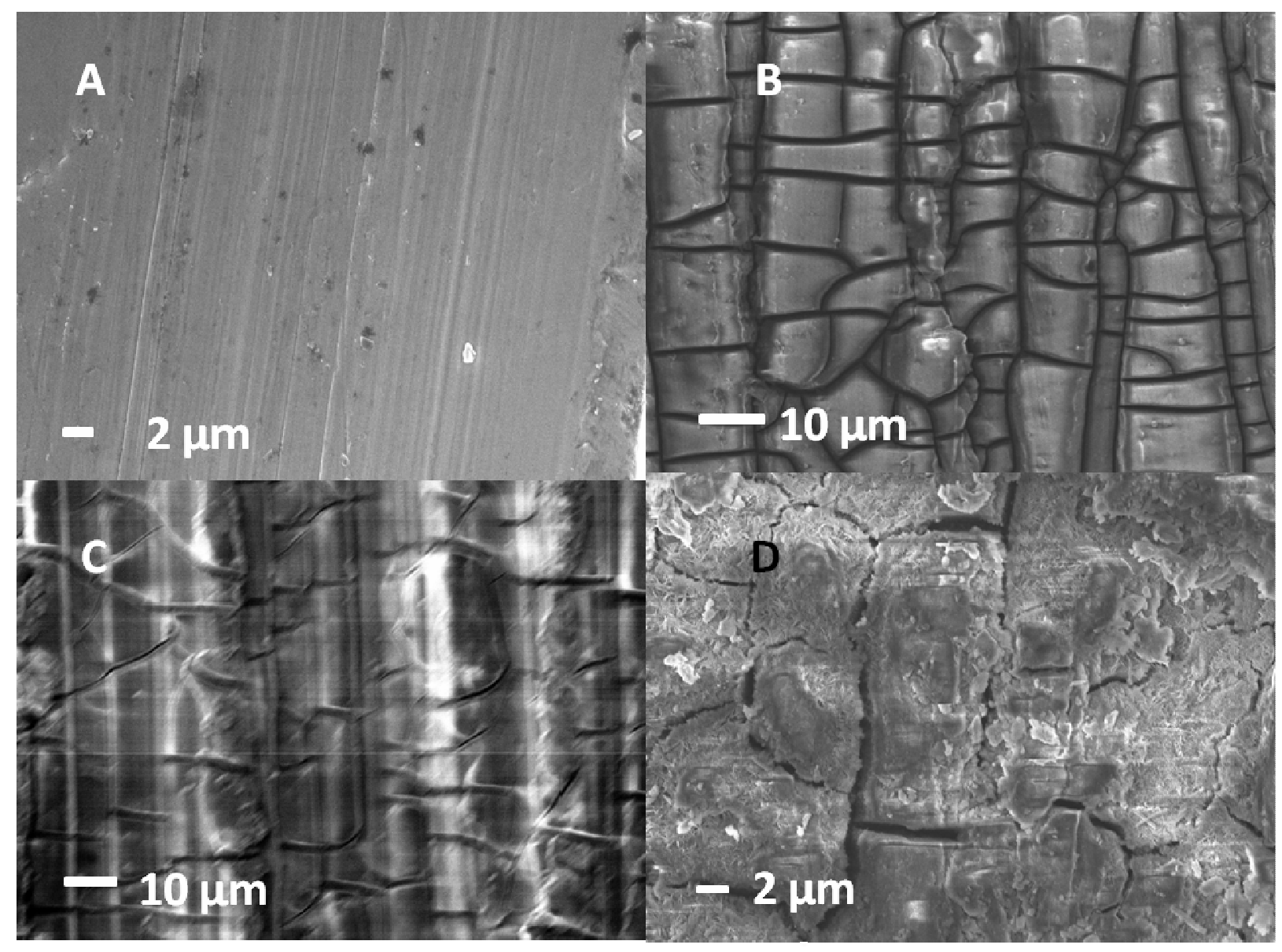

Figure 5 


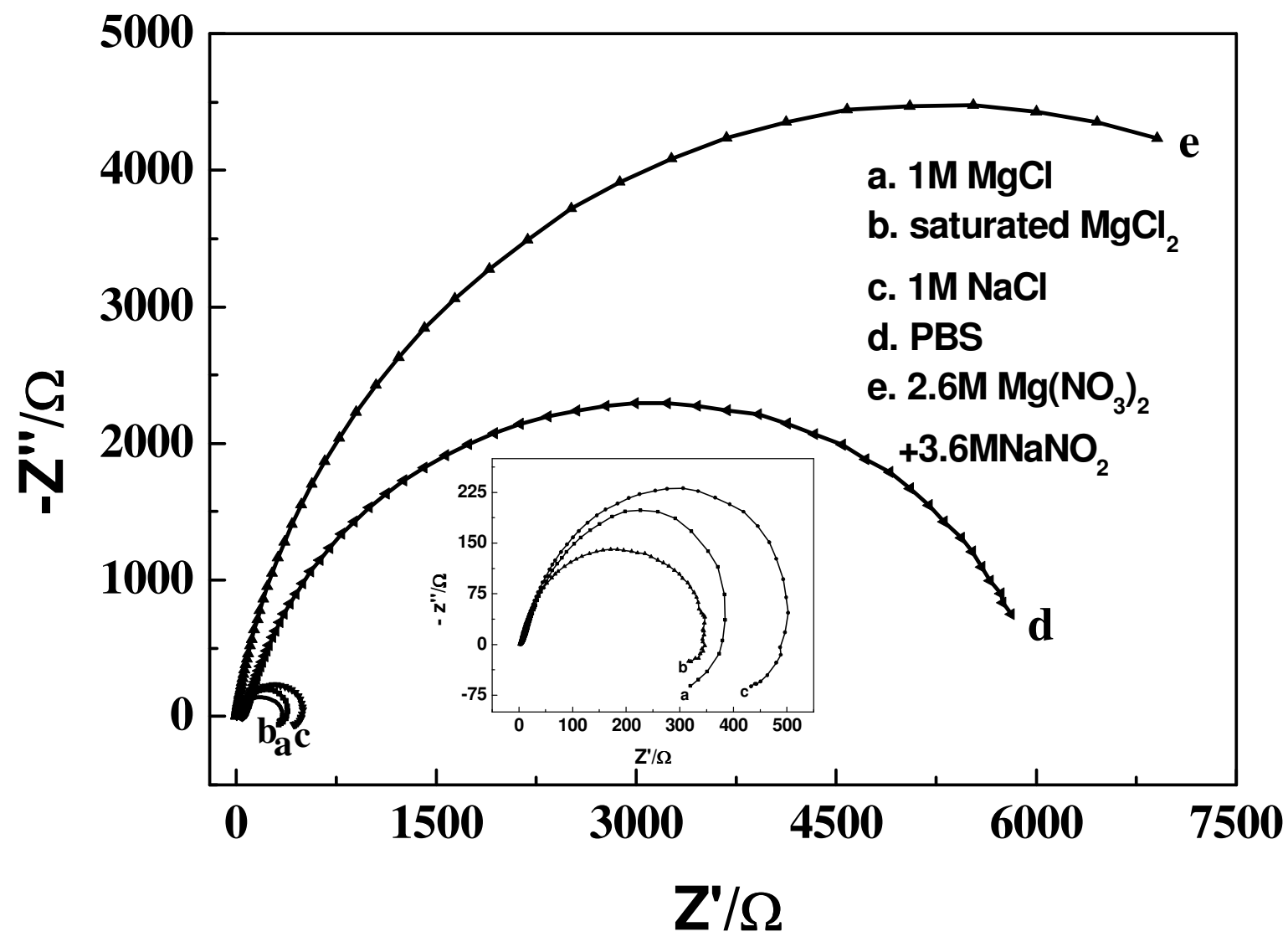

Figure 6 